\title{
Ocular sarcoidosis: our reality for the past six years
}

\author{
Sarcoidose ocular: a nossa realidade \\ nos últimos seis anos
}

Inês Coutinho', Ana Bastos Furtado², Cristina Santos', Susana Pina', Maria Lisboa', Isabel Ferreira², Bruno Grima², Manuela Bernardo ${ }^{1}$

\begin{abstract}
Purpose: In sarcoidosis, ocular manifestations are common and can be the initial or even the only clinical manifestation. The aim of this study was to analyze the demographic parameters, clinical manifestations, treatment and the major ocular complications in patients with ocular sarcoidosis. Methods: We conducted a descriptive and retrospective study that included patients with the diagnosis of ocular sarcoidosis, followed by inflammatory ophthalmology and immune-mediated disease consults at the Prof. Doutor Fernando Fonseca Hospital, between 2009 and 2015. Results: Eleven patients with the diagnosis of ocular sarcoidosis were identified, with a predominance of females (54,5\%) and Caucasians. The average age at diagnosis was $45 \pm 14$ years. Sarcoidosis was exclusively ocular in $36 \%$. The first manifestation of sarcoidosis was eye disease in $90.9 \%$ of cases. Nine cases of uveitis, one of nodular scleritis and one of interstitial keratitis were observed. Topical corticoid treatment was applied in 100\% of cases, with only one achieving remission of the disease. Oral corticoid treatment was necessary in 10 cases, four of which needed a high dose methylprednisolone induction. Methotrexate was the adjunctive immunosuppressive treatment of choice in $45 \%$ of cases. There was one refractory case for conventional immunosuppressive therapy, having achieved remission with biologic agent infliximab.Conclusion: Uveitis was the commonest ocular manifestation, and there was a predominance of panuveitis. Systemic corticoid and methotrexate were the most used immunosuppressive treatments for maintaining the controlled stated of the disease.
\end{abstract}

Keywords: Sarcoidosis; Ocular sarcoidosis, Corticosteroid/therapeutic use; Methotrexate/therapeutic use; Infliximab/therapeutic use

\section{ResUMO}

Introdução: Na sarcoidose, as manifestações oculares são comuns e podem constituir a manifestação inicial da doença ou mesmo a única. O objetivo deste trabalho foi analisar os parâmetros demográficos, manifestações clínicas, terapêutica e principais complicações oculares em doentes com sarcoidose ocular. Métodos: Estudo descritivo e retrospectivo que incluiu doentes com o diagnóstico de sarcoidose ocular, observados nas consultas de Inflamação Ocular e de Doenças Auto-Imunes do Hospital Prof. Doutor Fernando Fonseca, no período entre 2009 e 2015. Resultados: Foram identificados 11 doentes com o diagnóstico de sarcoidose ocular, com predomínio do sexo feminino (54,5\%) e caucasianos. A média da idade ao diagnóstico foi de $45 \pm 14$ anos. A sarcoidose manifestou-se de forma exclusivamente ocular em $36 \%$ dos casos. O envolvimento ocular foi a manifestação inicial em $90,9 \%$ dos casos. Identificaram-se 9 casos de uveíte, 1 de esclerite anterior nodular e 1 de queratite intersticial. O tratamento com corticoterapia tópica foi realizado em $100 \%$ dos casos, sendo o tratamento único em apenas 1 doente. Nos restantes, foi necessário associar corticoterapia oral. Em 4 desses doentes, pela gravidade da doença e atingimento binocular, utilizou-se também corticoterapia pulsada endovenosa. O tratamento adjuvante imunossupressor mais frequentemente utilizado foi o metotrexato $(45 \%)$. Um doente necessitou de terapia biológica com infliximabe para controle da doença. Conclusão: A manifestação ocular mais comum foi a uveíte, com predomínio da panuveíte. O tratamento mais utilizado e com maior taxa de controle da doença foi a corticoterapia sistêmica em associação com o metotrexato.

Descritores: Sarcoidose; Sarcoidose ocular; Corticoterapia/uso terapêutico; Metotrexato/uso terapêutico; Infliximabe/uso terapêutico

\footnotetext{
${ }^{1}$ Ophthalmology Service of Hospital Prof. Doutor Fernando Fonseca

2 Internal Medicine Service of Hospital Prof. Doutor Fernando Fonseca
}

The authors declare no conflicts of interests.

Received for publication 19/08/2015 - Accepted for publication 07/10/2015 


\section{INTRODUCTION}

0 arcoidosis is a systemic inflammatory disease characterized by the formation of noncaseating granulomas in the organs and tissues involved. The pathophysiological mechanism is not fully understood yet, and is the result of a complex immune process mediated by Th1 and Th17 cell response. Response patterns were identified in association to genetic and environmental factors, whether in the presentation form of antigen (determined by MHC2 alleles) or in the form how the immune response is developed and maintained [regulatory $\mathrm{T}$ cells (Tregs)]. ${ }^{(1,2)}$ The disparity observed among individuals with regard to the clinical course of the disease can be explained by the different ability to develop and control the immune response. Sarcoidosis can be self-limiting, without the need of therapeutic intervention, or can become persistent and develop to chronicity, requiring suppression by pharmacological means.

Epidemiologically, it is more common in young female adults aged from 20 to 40 years, and in European women after the age of 50 , where a second peak of incidence is described ${ }^{1}$. It can affect all ethnic groups, although it is reported with greater frequency in individuals from Northern Europe and in the black race..$^{(1,2)}$

Sarcoidosis can involve any organ, the lung being the main organ affected ( $90 \%$ of cases). The skin and eye attainment are common with an estimated prevalence of 20 to $35 \%$ and 10 to $60 \%$ respectively. . $^{(3-5)}$

Sarcoidosis can be the initial manifestation of ocular disease or even the only one. ${ }^{(3,6)}$ It can affect all structures of the eyeball and attachments, but classically the bilateral granulomatous anterior uveitis is the most common ocular manifestation.

Diagnosis is made by a detailed evaluation of all clinical, imaging, histological, cytological information and exclusion of other causes of granulomatous disease such as tuberculosis. ${ }^{(1,7)}$ Obtaining noncaseating granulomas in the histological sample confirms the diagnosis. However, it is not always possible to have a biopsy of the affected tissues, in particular in the patient with isolated uveitis. So, given the wide variety of systemic and ocular manifestations, the International Workshop on Ocular Sarcoidosis (IWOS) proposed 7 clinical signs and 5 laboratory and imaging results in order to assist and support the diagnosis of ocular sarcoidosis (Table 1). ${ }^{(8-11)}$

According to the criteria proposed by IWOS, a diagnosis of ocular sarcoidosis can range from possible to definitive (Table 2 ), after the exclusion of other causes of uveitis, especially tuberculosis, syphilis, toxoplasmosis and lymphoma. A global and detailed evaluation of the patient by experienced clinicians is therefore essential in systemic diseases such as sarcoidosis. ${ }^{(12)}$

The treatment of sarcoidosis, particularly ocular sarcoidosis, aims to halt the inflammatory process and is guided by the severity of the disease presentation, i.e., more intense inflammatory activity with loss or risk of loss of vision requires a more aggressive initial immunosuppressive approach. The treatment may be topical in the uveitis with previous location or associated to systemic therapy in cases of intermediate ou posterior uveitis, or if refractory to topical therapy. The systemic treatment includes classic immunosupressants drugs such as corticosteroids, azathioprine, methotrexate and Cyclosporine. ${ }^{(13)}$ Methotrexate is the most widely used corticosteroid-sparing drug in the series reported ${ }^{(14,15)}$, with positive results in chronic uveitis by sarcoidosis. In cases refractory to classic immunosuppressive therapy, biological therapy with the monoclonal antibody antiTNF á infliximab has shown very positive results. ${ }^{(16,17)}$
Table 1

\section{Clinical signs, laboratory tests and imaging suggestive of the diagnosis of ocular sarcoidosis}

\section{Ocular clinical signs}

1. Granulomatous keratic precipitates and/or iris nodules (Koeppe/Busacca)

2. Nodules on trabecular meshwork and/or peripheral anterior synechiae in tent form

3. Vitritis, snowballs and vitreous infiltrated in "string of pearls"

4. Active or atrophic peripheral chorioretinal lesions (Dalen Fuchs nodules)

5. Nodular or segmental periphlebitis (wax drop) and/or retinal macroaneurysm

6. Granulomas of the optic disc and /or solitary choroidal

7. Bilateralism

\section{Investigational tests}

1. Negative tuberculin test

2. High serum values of ACE e/ou Lysozyme

3. Chest x-rays revealing bilateral hilar adenopathy

4. High liver enzymes (AST, ALT, alkaline phosphatase)

5. Chest $C T$ with changes in patient with negative chest $x$-ray

Table 2

Diagnostic criteria of ocular sarcoidosis

\section{Diagnostic criteria}

1. DEFINITIVE

ocular sarcoidosis

Confirmation by biopsy and compatible uveitis

2. PRESUMED ocular sarcoidosis

Biopsy not doneBilateral hilar adenopathy + compatible uveitis

3. PROBABLE ocular sarcoidosis

Biopsy not performed and absence of bilateral hilar adenopathy 3 Suggestive intraocular signs +2 positive investigational tests

$\begin{array}{ll}\text { 4. POSSIBLE } & \text { Biopsy negative 4 Suggestive } \\ \text { ocular sarcoidosis } & \begin{array}{l}\text { intraocular signs }+2 \text { positive } \\ \text { investigational tests }\end{array}\end{array}$

\section{Methods}

A descriptive and retrospective study included 11 patients with diagnosis of sarcoidosis observed in the appointments of Eye Inflammation and Auto-Immune Diseases at the Hospital Prof. Doctor Fernando Fonseca, Portugal, between June 2009 and January 2015.

\section{RESULTS}

Demographic characteristics

Of the 11 individuals studied with ocular sarcoidosis, 6 women $(54.5 \%)$ and 5 men (45.5\%) were identified. 
The average age at date of diagnosis was $45 \pm 14$ years, most patients $(90.9 \%)$ being caucasians.

\section{Diagnosis}

The eye disease was the first clinical manifestation in $90.9 \%$ of the sample $(\mathrm{n}=10)$, leading to research and diagnosis of sarcoidosis.

Sarcoidosis is expressed exclusively in the ocular form in $36 \%(n=4)$ of the cases and $63.6 \%(n=7)$ systemically with ganglion predominance of mediastinal location of $63.6 \%(n=7)$ and pulmonary parenchyma $36.4 \%(n=4)$ (Table 1$)$. The average time between the first ocular manifestation and the systemic ones was 9.8 months [0-36M]. In addition to clinical observation, additional diagnostic test performed which assisted the most the diagnosis was chest CT. It was possible to confirm the diagnosis with the histologic sampling containing noncaseating granulomas in $45 \%(n=5)$ of cases.

Table 1

\section{Location of systemic involvement}

\begin{tabular}{lc}
\hline Systemic involviment & Número of patients (\%) \\
\hline Mediastinal ganglia & $7(63.6)$ \\
Pulmonary parenchyma & $4(36.4)$ \\
Musculoskeletal & $1(9)$ \\
Skin & $1(9)$ \\
Central nervous system & $1(9)$ \\
Cardiovascular System & $1(9)$ \\
\hline
\end{tabular}

According to the diagnostic criteria of the International Workshop on Ocular Sarcoidosis (IWOS), the cases of Uveitis $(\mathrm{n}=9)$ were classified as definite $(\mathrm{n}=5)$, presumed $(\mathrm{n}=1)$, and probable $(n=3)$ ocular sarcoidosis.

\section{Characterization of ocular involvement}

The bilateral ocular involvement expressed in $54.5 \%$ of the sample.

Uveitis was the most frequent ocular manifestation with $81 \%$ of prevalence $(n=9)$, followed by 1 case of anterior scleritis and 1 of interstitial keratitis (Figure 1).

Of the 9 patients with uveitis, 2 had anterior uveitis and 7 panuveitis, not being observed isolated posterior involvement (Figure 2).

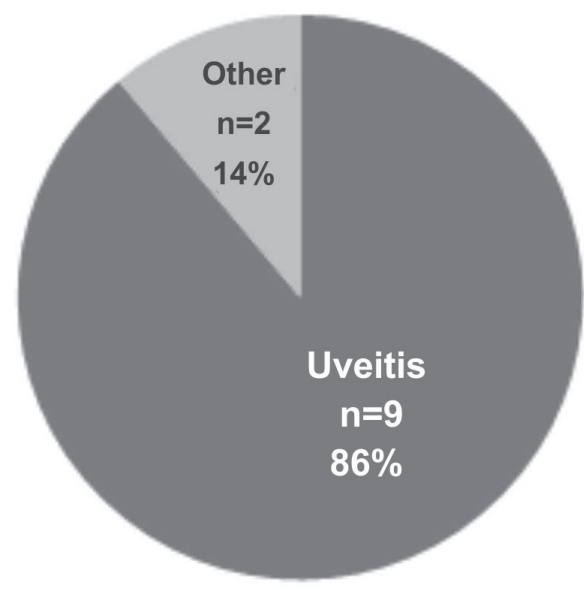

Figure 1. Ocular manifestations of sarcoidosis

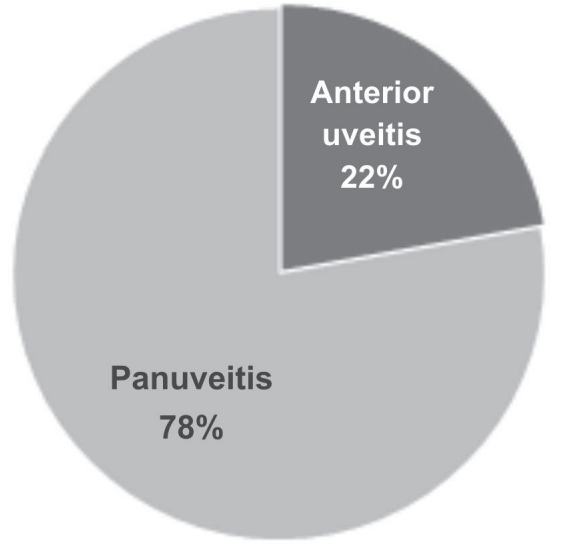

Figure 2. Uveitis type

Ocular inflammation was presented as granulomatous uveitis in 4 patients (Figure 3 ) and not granulomatous in 5 patients. This data emphasizes that ocular sarcoidosis can also manifest in the form of non-granulomatous anterior uveitis.

The formation of posterior synechiae was frequent (Figure 4), not being documented nodules in the iris (Koeppe or Busacca).

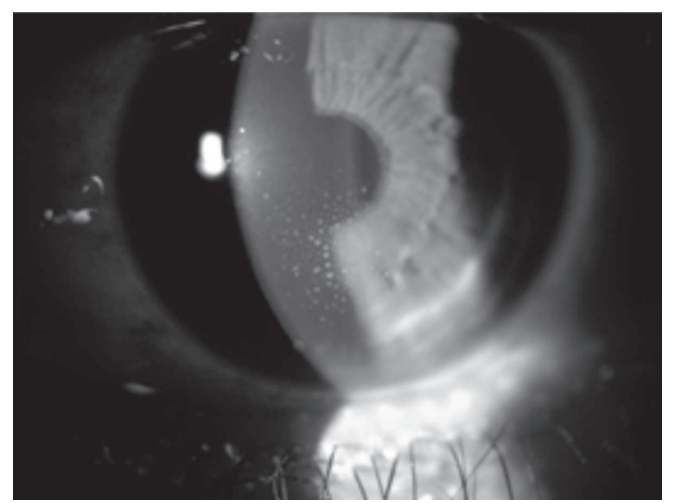

Figure 3: Keratic precipitates in "mutton fat"

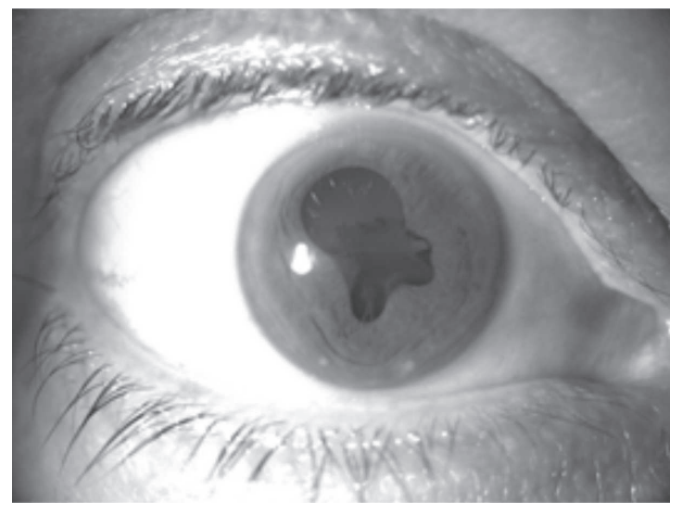

Figure 4: Posterior Synechia

The involvement of the posterior segment manifested with vitritis, and in some cases with vitreous opacities of the types snowballs, papillitis, isolated choroidal granuloma, chorioretinal injuries and retinal vasculitis with segment sheathing of retinal veins, sometimes associated to exudates in "wax drops" (Figures 5 and 6 ) 

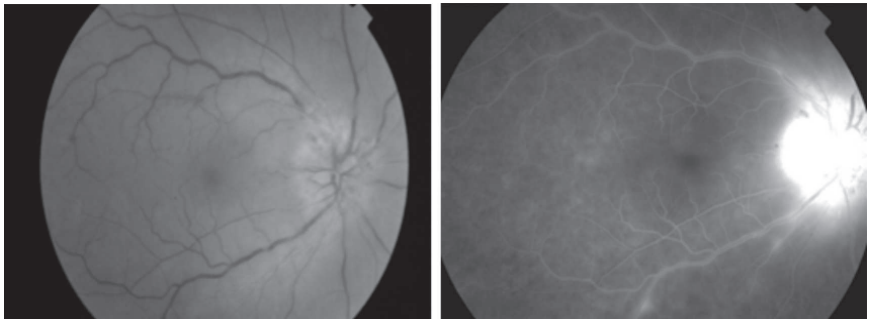

Figure 5: Segmental papillitis and periphlebitis (retinography and angiography)

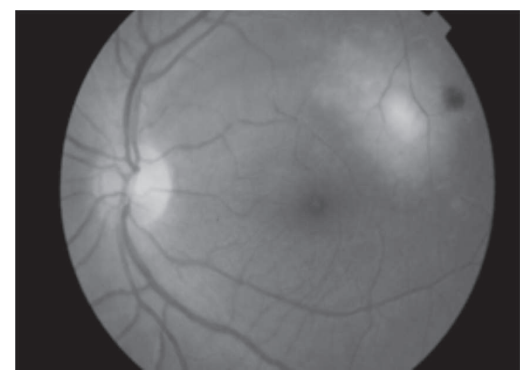

Figure 6: Isolated choroidal granuloma

The impairment of the episclera and sclera with episcleritis and scleritis are frequent demonstrations, while the corneal involvement is rare. In our analysis, a case of nodular anterior scleritis (Figure 7) and another of interstitial keratitis (Figure 8) were identified.

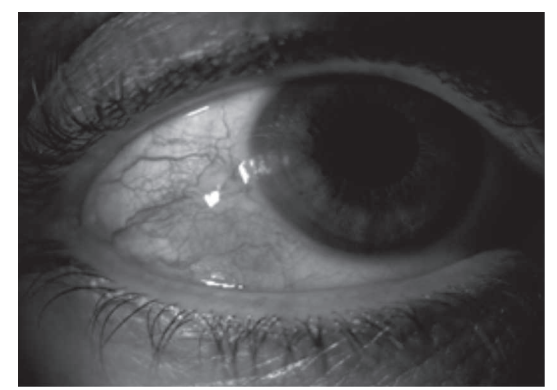

Figure 7: Nodular anterior scleritis

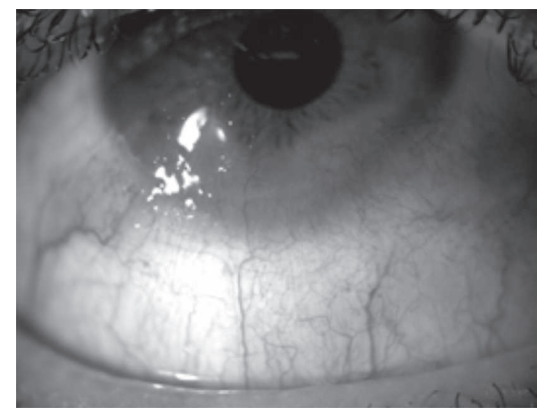

Figure 8: Interstitial keratitis with corneal neovascularization

\section{Complications and visual acuities}

The ocular prognosis is relatively benign, and some patients may develop severe ocular complications with low visual acuity.

Ocular complications have been documented in 5 of the 11 patients who included posterior synechiae $(n=3)$, cataract $(n=2)$, ocular hypertension $(\mathrm{n}=1)$, glaucoma $(\mathrm{n}=1)$ and macular edema $(\mathrm{n}=1)$.
The visual acuities (VA) of the 39 patients ranged from 6/ 10 to $10 / 10$, except for one patient in which the VA was $1 / 10$ due to developing nuclear cataract with posterior synechiae to $360^{\circ}$, and who is waiting for surgery.

\section{Therapy}

Patients with a diagnosis of ocular sarcoidosis were referred to the appointment of the Autoimmune Diseases of the IV Medicine Service for the study of systemic involvement and, when necessary, start the appropriate therapy.

Topical corticosteroids have been used in all patients $(100 \%)$, and the disease was controled in one case. In the remaining patients $(n=10)$, it was necessary to establish a systemic immunosuppressive therapy.

Given the severity of the ocular presentation, 4 patients $(36 \%)$ were treated with intravenous methylprednisolone in high dose $(1 \mathrm{~g} /$ day $)$, followed by oral prednisolone $(1 \mathrm{mg} / \mathrm{kg} /$ day $)$, and subsequent adjuvant immunosuppressive therapy with methotrexate (10mg/week). One of these patients (patient №. 5 Table 2) kept refractory disease, and the association to other classic immunosuppressants, azathioprine and cyclosporine was tempted without effectiveness and with the need for systemic corticosteroid therapy in very high doses. So, given the severity of the clinical profile the treatment with anti-TNF á (infliximab in association with methotrexate) was started, with a good and safe response.

Of the remaining patients in need of systemic therapy, 3 held only oral corticosteroid therapy and 1 oral corticosteroid therapy in association with methotrexate, with control of the disease.

\section{Discussion}

The main ocular manifestation of sarcoidosis was uveitis, and $90.9 \%$ of the patients the ocular disease was the first clinical manifestation, which supports the ocular impairment as an early manifestation of the disease. ${ }^{(17)}$

Ocular involvement in sarcoidosis varies with race and age, with the involvement of the posterior segment being more common in caucasians and of the anterior segment in the black race $^{(18)}$, which explains in part the large posterior involvement found in the sample studied.

Although not occuring in our study, the involvement of the conjunctiva and iris with granulomas, and the inflammation of the lacrimal gland may occur, affecting an increase thereof and secondarily sicca keratoconjunctivitis, as well as the involvement of the orbit and the extraocular muscles, sometimes simulating a condition of thyroid orbitopathy or non-specific inflammation of the orbit. ${ }^{(3,6,19)}$

The topical and/or oral corticosteroid therapy is the immunosuppressive treatment of choice, but in refractory cases or in need of savers of oral corticosteroids the methotrexate was the most widely used alternative and with a good rate of disease control.

\section{Conclusion}

Ocular involvement is a common and early manifestation of sarcoidosis.

The average time elapsed between the first and the systemic eye manifestations can be years, in our sample the maximum observed was 36 months. Therefore, these patients should remain under medical supervision by an expert in systemic diseases, since it is not always easy to establish the diagnosis at an early 
Table 2

Characteristics analysed in each case

\begin{tabular}{|c|c|c|c|c|c|c|c|c|c|c|c|c|c|c|}
\hline \multirow[t]{3}{*}{$\mathbf{N}$} & \multirow{3}{*}{$\begin{array}{c}\begin{array}{c}\text { Age at } \\
\text { diagnosis } \\
\text { (years) }\end{array} \\
\end{array}$} & \multirow[t]{3}{*}{ Sex } & \multicolumn{9}{|c|}{ Clinic } & \multirow{3}{*}{$\begin{array}{c}\text { Class uveitis } \\
\text { IWOS }\end{array}$} & \multicolumn{2}{|c|}{ MCDTs } \\
\hline & & & \multicolumn{3}{|c|}{$\begin{array}{c}\text { Initial } \\
\text { manifestation }\end{array}$} & \multicolumn{4}{|c|}{ Organ involved } & \multirow[b]{2}{*}{ Skin } & & & hest CT & \multirow[t]{2}{*}{$\mathbf{B x}$} \\
\hline & & & & Eye & Lung & Ganglia & NS & MSK & $\mathrm{CV}$ & & GI & & & \\
\hline 1 & 48 & $\mathrm{~F}$ & Ocular & Ant. uveitis & $\varnothing$ & $\mathbf{Y}$ & $\varnothing$ & $\mathbf{Y}$ & $\varnothing$ & $\varnothing$ & $\varnothing$ & Probable & $\mathbf{Y}$ & $\varnothing$ \\
\hline 2 & 55 & $\mathrm{~F}$ & Ocular & Panuveitis & $\mathbf{Y}$ & $\mathbf{Y}$ & $\mathbf{Y}$ & $\varnothing$ & $\varnothing$ & $\mathbf{Y}$ & $\varnothing$ & Definitive & $\mathbf{Y}$ & $\mathbf{Y}$ \\
\hline 3 & 28 & M & Ocular & Panuveitis & $\varnothing$ & $\varnothing$ & $\varnothing$ & $\varnothing$ & $\varnothing$ & $\varnothing$ & $\varnothing$ & Presumed & $\mathbf{Y}$ & $\varnothing$ \\
\hline 4 & 71 & M & Ocular & Panuveitis & $\mathbf{S}$ & $\mathbf{Y}$ & $\varnothing$ & $\varnothing$ & $\mathbf{Y}$ & $\varnothing$ & $\varnothing$ & Definitive & Y & $\mathbf{Y}$ \\
\hline 5 & 31 & $\mathrm{M}$ & Ocular & $\begin{array}{l}\text { Instersticial } \\
\text { keratitis }\end{array}$ & $\varnothing$ & $\varnothing$ & $\varnothing$ & $\varnothing$ & $\varnothing$ & $\varnothing$ & $\varnothing$ & $\varnothing$ & $\mathbf{Y}$ & $\varnothing$ \\
\hline 6 & 53 & $\mathrm{~F}$ & Ocular & Panuveitis & Y & $\mathbf{Y}$ & $\varnothing$ & $\varnothing$ & $\varnothing$ & $\varnothing$ & $\varnothing$ & Definitive & $\mathbf{Y}$ & $\mathbf{Y}$ \\
\hline 7 & 45 & $\mathrm{~F}$ & Systemic & Panuveitis & $\varnothing$ & $\mathbf{Y}$ & $\varnothing$ & $\varnothing$ & $\varnothing$ & $\varnothing$ & $\varnothing$ & Definitive & $\mathbf{Y}$ & $\mathbf{Y}$ \\
\hline 8 & 29 & M & Ocular & Ant. Scleritis & $\varnothing$ & $\varnothing$ & $\varnothing$ & $\varnothing$ & $\varnothing$ & $\varnothing$ & $\varnothing$ & $\varnothing$ & $\mathbf{Y}$ & $\varnothing$ \\
\hline 9 & 30 & M & Ocular & Panuveitis & $\mathbf{Y}$ & $\mathbf{Y}$ & $\varnothing$ & $\varnothing$ & $\varnothing$ & $\varnothing$ & $\varnothing$ & Probable & $\mathbf{Y}$ & $\varnothing$ \\
\hline 10 & 45 & $\mathrm{~F}$ & Ocular & Ant. uveitis & $\varnothing$ & $\mathbf{Y}$ & $\varnothing$ & $\varnothing$ & $\varnothing$ & $\varnothing$ & $\varnothing$ & Definitive & $\mathbf{Y}$ & $\mathbf{Y}$ \\
\hline 11 & 61 & $\mathrm{~F}$ & Ocular & Panuveitis & $\varnothing$ & $\varnothing$ & $\varnothing$ & $\varnothing$ & $\varnothing$ & $\varnothing$ & $\varnothing$ & Probable & $\mathbf{Y}$ & $\varnothing$ \\
\hline
\end{tabular}

$\mathbf{N}$

Terapy

Status of the disease

Topic

Systemic

\begin{tabular}{llllll}
\hline MPDN & PDN & MTX & AZAT & CICLOSP & Anti-TNF - INF
\end{tabular}

$\begin{array}{ll}\mathbf{1} & \mathrm{Y} \\ \mathbf{2} & \mathrm{Y} \\ \mathbf{3} & \mathrm{Y} \\ \mathbf{4} & \mathrm{Y} \\ \mathbf{5} & \mathrm{Y} \\ \mathbf{6} & \mathrm{Y} \\ \mathbf{7} & \mathrm{Y} \\ \mathbf{8} & \mathrm{Y} \\ \mathbf{9} & \mathrm{Y} \\ \mathbf{1 0} & \mathrm{Y} \\ \mathbf{1 1} & \mathrm{Y}\end{array}$

$\begin{array}{lll}\varnothing & \varnothing & \varnothing \\ \mathrm{Y} & \mathrm{Y} & \varnothing \\ \mathrm{Y} & \mathrm{Y} & \varnothing \\ \mathrm{Y} & \varnothing & \varnothing \\ \mathrm{Y} & \mathrm{Y} & \mathrm{Y} \\ \mathrm{Y} & \varnothing & \varnothing \\ \mathrm{Y} & \varnothing & \varnothing \\ \mathrm{Y} & \mathrm{Y} & \varnothing \\ \mathrm{Y} & \varnothing & \varnothing \\ \mathrm{Y} & \mathrm{Y} & \varnothing \\ \mathrm{Y} & \varnothing & \varnothing\end{array}$

$\begin{array}{ll}\varnothing & \varnothing \\ \varnothing & \varnothing \\ \varnothing & \varnothing \\ \varnothing & \varnothing \\ \mathrm{Y} & \mathrm{Y} \\ \varnothing & \varnothing \\ \varnothing & \varnothing \\ \varnothing & \varnothing \\ \varnothing & \varnothing \\ \varnothing & \varnothing \\ \varnothing & \varnothing\end{array}$

Controled

Controled

Controled

Controled

Controled

Controled

Controled

Controled

Controled

Controled

Controled

Caption: N. patient; $\mathrm{Y}=$ yes; $\varnothing=$ no; MDPN methylprednisolone; PDN prednisolone; MTX methotrexate, AZAT azathioprine; CICLOSP cyclosporin, INF infliximab

stage of the disease. The clinical development of the disease can be one of the most important data for the diagnosis and subsequent therapeutic control. Awareness of the difficulty in diagnosis goes along with the treatment. Ocular inflammatory disease may have significant implications on visual acuity, and may lead to the development of potentially irreversible lesions. At the same time, the choice of immunosuppressive therapy is difficult and not without harmful side effects, both locally and systemically.

The multiplicity of forms of presentation without pathognomonic signs together with the fact of organ involvement does not necessarily cause symptoms makes it challenging to diagnose and give therapeutic guidance for these patients, requiring interdisciplinary work between physicians.

\section{ACKNOWLEDGEMENTS}

To the IV Medicine Service of Hospital Prof. Doutor Fernando Fonseca

\section{ReFERENCES}

1. Valeyre D, Prasse A, Nunes H, Uzunhan Y, Brillet PY, MüllerQuernheim J. Sarcoidosis. Lancet. 2014;383(9923):1155-67. Review. 
2. Broos CE, van Nimwegen M, Hoogsteden HC, Hendriks RW, Kool M, van den Blink B.Granuloma formation in pulmonary sarcoidosis. Front Immunol. 2013;4:437. Review.

3. Rothova A. Ocular involvement in sarcoidosis. Br J Ophthalmol. 2000;84(1):110-6. Review.

4. Jamilloux Y, Kodjikian L, Broussolle C, Sève P. Sarcoidosis and uveitis. Autoimmun Rev. 2014;13(8):840-9.

5. Oréfice F, Santos D, Oréfice J. Uveítes. 2a ed. Rio de Janeiro: Cultura Médica: Guanabara Koogan; 2011.

6. Bustelo M, Garcia S. Tratamiento de la sarcoidosis ocular. Rev Esp Inv Oftal. 2012; 2(4):273-8.

7. Heinle R, Chang C. Diagnostic criteria for sarcoidosis. Autoimmun Rev. 2014;13(4-5):383-7. Review.

8. Papadia M, Herbort CP, Mochizuki M. Diagnosis of ocular sarcoidosis. Ocul Immunol Inflamm. 2010;18(6):432-41.

9. Gil J. Sarcoidose ocular. [dissertação de mestrado] Coimbra: Faculdade Medicina Universidade de Coimbra; 2011.

10. Herbort CP, Rao NA, Mochizuki M; members of Scientific Committee of First International Workshop on Ocular Sarcoidosis. International criteria for the diagnosis of ocular sarcoidosis: results of the first International Workshop On Ocular Sarcoidosis (IWOS). Ocul Immunol Inflamm. 2009;17(3):160-9.

11. Takase H, Shimizu K, Yamada Y, Hanada A, Takahashi H, Mochizuki M. Validation of international criteria for the diagnosis of ocular sarcoidosis proposed by thefirst international workshop on ocular sarcoidosis. Jpn J Ophthalmol. 2010;54(6):529-36.
12. Baughman RP, Lower EE, Kaufman AH. Ocular sarcoidosis. Semin Respir Crit Care Med. 2010;31(4):452-62.Review.

13. Smith JR, Rosenbaum JT. Management of uveitis: a rheumatologic perspective.Arthritis Rheum. 2002;46(2):309-18. Review.

14. Dev S, McCallum RM, Jaffe GJ. Methotrexate treatment for sarcoid-associated panuveitis. Ophthalmology. 1999;106(1):111-8.

15. Baughman RP, Lower EE, Ingledue R, Kaufman AH. Management of ocular sarcoidosis. Sarcoidosis Vasc Diffuse Lung Dis. 2012;29(1):26-33.

16. Cottin V. Update on bioagent therapy in sarcoidosis. F1000 Med Rep. 2010;2.pii:13.

17. Rao DA, Dellaripa PF. Extrapulmonary manifestations of sarcoidosis. Rheum Dis Clin North Am. 2013;39(2):277-97. Review.

18. Bodaghi B, Touitou V, Fardeau C, Chapelon C, LeHoang P. Ocular sarcoidosis. Presse Med. 2012;41(6 Pt 2):e349-54

19. Nussenblatt RB, Whitcup SM. Uveitis. Fundamentals and Clinical Practice - fourth edition. Los Angeles: Mosby Elsevier, 2010

\section{Corresponding author:}

Inês Coutinho

E-mail: inescorga@gmail.com 